\title{
BIOMASS ALLOCATION AND WATER USE EFFICIENCY IN FERTIGATED SWEET PEPPER
}

\author{
FRANCIMAR DA S. ALBUQUERQUE ${ }^{1}$, ÊNIO F. DE F. E SILVA ${ }^{2}$, \\ MARCUS F. F. N. NUNES ${ }^{3}$, AMANDA E. R. DE SOUZA ${ }^{4}$
}

\begin{abstract}
The use of productivity information and efficiency of water use is important for the economic analysis of production and irrigation management, and also helps the economy of water use, which is essential to plant life. The objective of this study was to evaluate the biomass allocation, the water use efficiency and water content in fruits of sweet pepper cropped under the influence of irrigation blades and potassium doses. The statistic design was a completely randomized factorial scheme $(5 \times 2)$ and four replications, with five irrigation blades $(80 ; 90 ; 100$; 110 and $120 \%$ of crop evapotranspiration) and two levels of potassium (80 and $120 \mathrm{~kg} \mathrm{~K}_{2} \mathrm{O} \mathrm{ha}^{-1}$ ), applied according to phenological phase, through a system of drip irrigation with self-compensated drippers, installed in a battery of 40 drainage lysimeters cultivated with sweet pepper (Maximos F1), at Federal Rural University of Pernambuco (UFRPE), Recife, state of Pernambuco, Brazil. The dry biomass production of sweet pepper was influenced by fertigation regimes; when it was set the lowest dose, estimates of the efficiency of water use and moisture in the fruit occurred with the use of irrigation depth of 97 and $95 \%$ of ETc, respectively.
\end{abstract}

KEYWORDS: irrigation blades, potassium levels, drainage lysimeters.

\section{ALOCAÇÃO DE BIOMASSA E EFICIÊNCIA DO USO DA ÁGUA EM PIMENTÃo FERTIRRIGADO}

RESUMO: O uso de informações de produtividade e eficiência do uso da água é importante para a análise econômica da produção e manejo da irrigação, e ainda auxilia na economia do uso da água, a qual é imprescindível à vida vegetal. Objetivou-se, com este trabalho, avaliar a alocação de biomassa seca, a eficiência do uso da água e o teor de água nos frutos de pimentão em cultivo sob influência de lâminas de irrigação e doses de potássio. O delineamento estatístico adotado foi inteiramente casualizado, com esquema fatorial $5 \times 2$ e quatro repetições, sendo cinco lâminas de irrigação $(80 ; 90 ; 100 ; 110$ e 120\% da evapotranspiração da cultura) e duas doses de potássio (80 e $120 \mathrm{~kg} \mathrm{~K}_{2} \mathrm{O} \mathrm{ha}{ }^{-1}$ ), aplicadas parceladamente, por intermédio de um sistema de irrigação por gotejamento, com emissores autocompensantes, instalados em uma bateria de 40 lisímetros de drenagem, cultivados com pimentão híbrido (Máximos F1), localizada no Câmpus da Universidade Federal Rural de Pernambuco (UFRPE), Recife-PE. A produção de biomassa seca do pimentão foi influenciada pelos regimes de fertirrigação; quando se fixou a menor dose, as estimativas da maior eficiência do uso da água e umidade nos frutos ocorreram com o emprego da lâmina de irrigação de 97 e $95 \%$ da evapotranspiração da cultura, respectivamente.

PALAVRAS-CHAVE: lâminas de irrigação, doses de potássio, lisímetros de drenagem.

\footnotetext{
${ }^{1}$ Eng $^{\circ}$ Agrônomo, Mestre em Engenharia Agrícola - Manejo Integrado de Água e Solo, UFRPE, franciufrpe@gmail.com.

${ }^{2}$ Eng ${ }^{\mathrm{O}}$ Agrícola, Prof. Adjunto, Departamento de Tecnologia Rural - DTR, Área de Recursos Hídricos, UFRPE, Recife - PE, enio.silva@pq.cnpq.br.

${ }^{3}$ Acadêmico em Agronomia, UFRPE, marcusnnunes@gmail.com.

${ }^{4}$ Eng ${ }^{\mathbf{a}}$ Agrônoma, Mestre em Agronomia - Melhoramento Genético de Plantas, UFPE, Recife - PE, amandarocha228@gmail.com.

Recebido pelo Conselho Editorial em: 29-10-2010

Aprovado pelo Conselho Editorial em: 10-12-2011
} 


\section{INTRODUCTION}

The species Capsicum annuum is a solanaceous perennial but grown as an annual culture. It is typically originated from America, occurring in wild forms from the southern of the United States to northern of Chile (FILGUEIRA, 2008). The peppers are among the crops that have a wide use of hybrids because they have high production potential.

The use of information productivity and efficiency of water use is important for the economic analysis of production and irrigation, and also helps the economy of water use (SANDRI et al., 2007).

Water is essential to plant's life and is more than $90 \%$ by weight of the usable part of most plants, being easy to show its importance in horticulture (FILGUEIRA, 2008).

The application of fertilizers with the irrigation water features a technique called fertigation. The use of this technique has enabled the optimization of inputs in different irrigated crops, both aspects related to productivity and the quality of the products obtained, being most notable its adoption in crops irrigated by drip irrigation systems (OLIVEIRA \& VILLAS BOAS, 2008), and that the uniformity of nutrients distribution is directly related to the uniformity coefficient of irrigation water (TRANI \& CARRIJO, 2004).

The water in the food can be assessed and measured by studying the activity of water which is, in general, evaluating the amount of water free or active in the food, and probably is the factor that most affects the individual modification of food, affecting their physical nature and properties (SILVA et al., 2010a).

This study aims to evaluate the allocation of biomass, the efficiency of water use and moisture in fruits of sweet pepper cultivated under the influence of irrigation blades and potassium doses.

\section{MATERIAL AND METHODS}

The experiment was conducted at the Lisimetric Station of the Department of Rural Technology (DRT), located at the Universidade Federal Rural de Pernambuco (UFRPE), Recife, PE, whose geographical coordinates in the system SAD 69 (South American Datum) is $8^{\circ} 011^{\prime} 05^{\prime \prime}$ south latitude and $34^{\circ} 56^{\prime} 48^{\prime \prime}$ west longitude and altitude of $6.50 \mathrm{~m}$.

The climate according to Koppen's classification, is the, megathermal tropical (tropical wet) with an average temperature of the coldest month above $18^{\circ} \mathrm{C}$ with autumn and winter rainfall.

The area of the experiment has of $464.40 \mathrm{~m}^{2}$ of planted area, which is installed a battery of 40 drainage lysimeters. The lysimeters are filled with sandy soil, classified as Neosoil Quartzarenic and each consisted of a box of cement reinforced with synthetic yarn, truncated cones, with a capacity of 1,000 L, external diameter at the upper edge $1,380 \mathrm{~mm}$ and external height of $745 \mathrm{~mm}$ (ALBUQUERQUE FILHO et al., 2009).

The statistical design was completely randomized with $5 \times 2$ factorial arrangement and four replications, five irrigation blades $(80 ; 90 ; 100 ; 110$ and $120 \%$ of crop evapotranspiration - ETc) and two doses of potassium ( 80 and $120 \mathrm{~kg} \mathrm{~K}_{2} \mathrm{O} \mathrm{ha}^{-1}$ ), applied in parcels.

The application was made through a drip irrigation system, with auto compensating emitters, on line, model Katif, button-type manufacturing Plastro, being three emitters per lysimeter. The emitter flow specified by the manufacturer is $3.75 \mathrm{~L} \mathrm{~h}^{-1}$, being the measurement field of $3.90 \mathrm{~L} \mathrm{~h}^{-1}$.

In the lysimeters peppers, Maximos F1 hybrid (EliSem-Clause Vegetable Seeds) were cultivated, which the experimental plot was composed of three plants in each lysimeter, with $0.40 \mathrm{~m}$ spacing between plants on line and $1.30 \mathrm{~m}$ between rows. The seedlings were purchased in a certified producer at the Ministry of Agriculture, Livestock and Supply.

To minimize the effect of advection on the treatments plants, pepper seedlings of the same hybrid were planted in the area between the lysimeters using the same spacing. 
The application uniformity of potassium doses and its relationship with the water distribution uniformity were determined at 60 and 120 days after transplantation using the Christiansen uniformity coefficient (CUC) and the coefficient of Distribution Uniformity (CDU) (BERNARDO et al., 2008), whose results are presented in Table 1, characterizing the system performance under optimal conditions.

TABLE 1. Christiansen Uniformity and Distribution Uniformity coefficients for doses $\mathrm{D}_{1}$ $\left(80 \mathrm{~kg} \mathrm{~K}_{2} \mathrm{O} \mathrm{ha}^{-1}\right)$ and $\mathrm{D}_{2}\left(120 \mathrm{~kg} \mathrm{~K}_{2} \mathrm{O} \mathrm{ha}{ }^{-1}\right)$.

\begin{tabular}{lcccccccc}
\hline \multirow{2}{*}{ Variables } & \multicolumn{2}{c}{ CUC $(\%)-60$ days } & \multicolumn{2}{c}{ CDU $(\%)-60$ days } & \multicolumn{3}{c}{ CUC $(\%)-120$ days CDU $(\%)-120$ days } \\
\cline { 2 - 9 } & $\mathrm{D}_{1}$ & $\mathrm{D}_{2}$ & $\mathrm{D}_{1}$ & $\mathrm{D}_{2}$ & $\mathrm{D}_{1}$ & $\mathrm{D}_{2}$ & $\mathrm{D}_{1}$ & $\mathrm{D}_{2}$ \\
\hline Water & 97.39 & 97.39 & 95.64 & 95.64 & 94.75 & 94.75 & 92.19 & 92.19 \\
EC & 89.53 & 89.24 & 82.46 & 82.69 & 85.74 & 87.33 & 80.18 & 81.65 \\
$\mathrm{~K}^{+}$ & 87.09 & 84.45 & 79.32 & 73.20 & 85.65 & 85.65 & 83.03 & 81.92 \\
\hline
\end{tabular}

$\mathrm{EC}, \mathrm{K}+=$ Electrical conductivity and potassium concentration.

Plants were watered daily, and the water blades were calculated from ETc, which was obtained by the following equation:

$$
\mathrm{ETc}=\mathrm{ETo} \mathrm{Kc} \mathrm{Kl}_{\text {med. }} \text {. }
$$

In which,

ETc - evapotranspiration, $\mathrm{mm} \mathrm{day}^{-1}$;

ETo - reference evapotranspiration by Penman-Monteith, $\mathrm{mm}_{\text {day }}{ }^{-1}$;

Kc - coefficient of cultivation, dimensionless, and

$\mathrm{Kl}_{\text {med. }}$ - coefficient of medium location, dimensionless.

To estimate the $\mathrm{kl}_{\text {med. }}$, it was used the average of four coefficients of location, according to PIZARRO (1996), which depends on the value of the shaded area fraction by the crop (S). To determine the value of $S$ it was used the recommendation submitted by the same author.

The ETo and rainfall were obtained from the automated weather station equipped with sensors and data store needed to determine the ETo of Penman-Monteith (Campbell Scientific model CR1000/CFM100/OS100), used in the calculation of irrigation according to the treatment.

The Kc values used daily according to phenological stage of the culture were: 0.40 (from emergency up to $10 \%$ of development - 30 days), 0.75 (10\% of development up to $75 \%$ of development - 40 days); 1.05 (flowering until the onset of maturation - 60 days), and 0.85 (from maturation until the last harvest - 20 days), according to TRANI \& CARRIJO (2004).

The fertilizers were used in fertigation purified monoammonium phosphate (MAP $\left.\mathrm{NH}_{4} \mathrm{H}_{2} \mathrm{PO}_{4}\right)$, calcium nitrate $\left(\mathrm{Ca}\left(\mathrm{NO}_{3}\right)_{2}\right)$, magnesium sulfate $\left(\mathrm{Mg}\left(\mathrm{SO}_{4}\right)_{2} .7 \mathrm{H}_{2} \mathrm{O}\right)$ and potassium chloride ( $\mathrm{KCl}$ red), by making the balance of nutrients required.

Daily doses of nitrogen, phosphorus, calcium, magnesium and potassium that were applied in fertigation followed recommendations of TRANI \& CARRIJO (2004), as shown in Table 2, and potassium dosages were adjusted to the conditions of the experiment.

In addition to macronutrients, two applications were made Quelatec AZ, a solid mixture of essential micronutrients chelated with EDTA, at a dosage of $2.50 \mathrm{~kg} \mathrm{ha}^{-1}$ recommended for pepper, 70 and 90 days after transplanting (DAT). 
TABLE 2. Recommendations of nutrients for sweet pepper, according to the development stage of the crop.

\begin{tabular}{cccccccc}
\hline Beginning of & Phases & \multicolumn{6}{c}{ Quantity of nutrients $\left(\mathrm{kg} \mathrm{ha}^{-1}\right.$ day $\left.^{-1}\right)$} \\
\cline { 3 - 7 } $\begin{array}{c}\text { Application } \\
\text { (DAT) }\end{array}$ & $\begin{array}{c}\text { Duration } \\
\text { (days) }\end{array}$ & $\mathrm{N}$ & $\mathrm{P}_{2} \mathrm{O}_{5}$ & $\mathrm{Ca}$ & $\mathrm{Mg}$ & $\mathrm{K}_{2} \mathrm{O}\left(\mathrm{D}_{1}\right)$ & $\mathrm{K}_{2} \mathrm{O}\left(\mathrm{D}_{2}\right)$ \\
\hline 1 & 5 & 0.05 & 0.01 & 0.03 & 0.04 & 0.01 & 0.02 \\
5 & 15 & 0.35 & 0.06 & 0.23 & 0.14 & 0.12 & 0.18 \\
20 & 20 & 1.16 & 0.24 & 0.69 & 0.50 & 0.35 & 0.52 \\
40 & 20 & 1.32 & 0.22 & 0.67 & 0.70 & 0.40 & 0.61 \\
60 & 20 & 2.63 & 0.77 & 1.93 & 1.05 & 0.74 & 1.12 \\
80 & 30 & 2.73 & 0.60 & 0.80 & 0.75 & 0.86 & 1.28 \\
110 & 40 & 3.75 & 1.10 & 1.00 & 0.72 & 0.75 & 1.13 \\
150 & 10 & 2.00 & 0.90 & 1.20 & 0.90 & 0.56 & 0.84 \\
\hline
\end{tabular}

At 112 days after transplanting, the plants were harvested, separated into leaves, stems and roots, and the organs were weighed on a precision balance $(0.01 \mathrm{~g})$ to obtain the wet weight, packed in paper bags, identified and brought for forced aeration oven at $65^{\circ} \mathrm{C}$ in the Laboratory of Mineral Nutrition of Plants, in the Agricultural Chemistry area, in the Department of Chemistry UFRPE (DQ/UFRPE). The material remained in the oven for 72 hours until constant mass. Then proceeded the reweighing the material to obtain the dry matter.

To determine the allocation of biomass, were calculated, leaf dry matter (LDM), stem (SDM), root $(\mathrm{RDM})$, total (TDM) (leaves + stem + root) and root / shoot ratio(R / S) per treatment. With the data of dry matter, calculated the biomass allocation to leaves (ABF), stems (ABC), roots (ABR) and the root / shoot ratio (R/S), according to SILVA et al. (2008).

The water use efficiency (WUE) was defined by the relationship between production, in $\mathrm{kg}$, and the amount of water applied, $\mathrm{m}^{3}$, expressed in $\mathrm{kg} \mathrm{m}^{-3}$, modification of the methodology proposed by Sousa et al. (2010).

From the total harvested fruit was removed a sample of three fruits per lysimeter, which were weighed on a precision balance $(0.01 \mathrm{~g})$ to obtain the wet weight and then were cut into pieces, packed in opened aluminum containers and taken for the same greenhouse at DQ/UFRPE for approximately 120 hours, until constant weight.

Then proceeded the reweighing the material for obtaining the dry matter. The moisture in the fruit (M) was determined by the following equation:

$$
\mathrm{M}=\frac{\text { FFM }- \text { FDM }}{\text { FFM }} 100
$$

where,

M - water content in fruits, $\%$;

FFM - fresh fruit, $\mathrm{g}$, and

FDM - fruit dry mass, g.

The data were analyzed in the computer system SISVAR Version 5.3 (System for Statistical Analyses) (FERREIRA, 2008) and interpreted by means of the significances of variance and regression, considering the level of probability to $5 \%$ by $\mathrm{F}$ test.

To establish a model to represent the phenomenon under study, it was used the " $t$ " Student test for the regression coefficients, taking the level of probability to $10 \%$ and coefficients of determination (R2).

The presentation of the regression equations and their interpretations were in accordance with the recommendation of ALVAREZ \& ALVAREZ (2003). The optimum irrigation blade was 
determined from the regression analysis, where the quadratic model was derived by obtaining the maximum point of the respective variable.

\section{RESULTS AND DISCUSSION}

Table 3 shows a significant effect on significance levels ranging from 1 to $0.1 \%$ probability of interaction between irrigation blade (I) $x$ dose (D) and isolated factors I and D for dry matter and biomass allocation of the vegetative organs.

TABLE 3. Summary of ANOVA of dry matter leaves (DML), stem (DMS), root (DMR), total (DMT), biomass allocation to leaves (BAL), stems (BAS), roots (BAR) and root/shoot ratio $(\mathrm{R} / \mathrm{S})$.

\begin{tabular}{|c|c|c|c|c|c|c|c|c|c|}
\hline \multirow{2}{*}{$\begin{array}{l}\text { Source of } \\
\text { variation }\end{array}$} & \multirow{2}{*}{ GL } & \multicolumn{8}{|c|}{ Average Squares } \\
\hline & & LDM & SDM & $\mathrm{RDM}$ & TDM & $\mathrm{ABF}$ & $\mathrm{ABC}$ & $\mathrm{ABR}$ & $\mathrm{R} / \mathrm{S}$ \\
\hline $\mathrm{I}(\% \mathrm{ETc})$ & 4 & $30.11 * * *$ & $36.60 * * *$ & $1.98^{\mathrm{NS}}$ & $92.27 * * *$ & $134.33 * * *$ & $138.19 * * *$ & $53.04 * * *$ & $0.0147 * * *$ \\
\hline $\mathrm{D}\left(\mathrm{kg} \mathrm{ha}^{-1}\right)$ & 1 & $124.57 * * *$ & $38.48 * * *$ & $2.94^{\mathrm{NS}}$ & $364.02 * * *$ & $257.87 * * *$ & $66.61 * *$ & $62.36^{* *}$ & $0.0184 * *$ \\
\hline I x D & 4 & $41.48 * * *$ & $45.91 * * *$ & $19.56^{* * *}$ & $239.32 * * *$ & $117.77 * * *$ & $115.53 * * *$ & $48.53 * * *$ & $0.0129 * * *$ \\
\hline esidues & 30 & 2.36 & 1.53 & 1.03 & 6.80 & 9.00 & 6.97 & 6.82 & 0.0019 \\
\hline C.V.\% & & 13.37 & 8.49 & 14.47 & 7.88 & 8.76 & 5.97 & 12.14 & 15.55 \\
\hline
\end{tabular}

${ }^{\mathrm{NS}}$ : not significant to $5 \%$, ** and $* * *$ : significant at a probability of $0.1 \%$ and the $\mathrm{F}$ test, respectively.

Table 4 shows the regression equations adjusted to the average data and the respective coefficients of determination (R2). From Table 5 it can be seen the estimates of irrigation blades and the data of dry matter of vegetative parts, biomass allocation and root / shoot ratio at each dose level of potassium.

TABLE 4. Regression equations adjusted to mean data from dry matter of leaves (DML), stem (DMS), root (DMR), total (DMT), biomass allocation to leaves (BAL), stems (BAS), roots (BAR) and root/shoot ratio $(\mathrm{R} / \mathrm{S})$, as a function of irrigation blades $(\mathrm{X})$ estimated in levels of potassium $\left(D_{1}\right.$ and $\left.D_{2}\right)$, with respective coefficients of determination $\left(R^{2}\right)$.

\begin{tabular}{|c|c|c|c|}
\hline \multicolumn{2}{|c|}{ Variables } & \multirow{2}{*}{$\begin{array}{l}\text { Adjusted Regression Equations } \\
\hat{Y}=0.21+0.095^{* * *} \mathrm{X}\end{array}$} & \multirow{2}{*}{$\frac{\mathrm{R}^{2}}{0.1420}$} \\
\hline LDM & $\left(\mathrm{D}_{1}\right)$ & & \\
\hline \multirow[t]{2}{*}{ SDM } & $\left(\mathrm{D}_{1}\right)$ & $\hat{\mathrm{Y}}=151.57-2.83 * * * \mathrm{X}+0.014 * * * \mathrm{X}^{2}$ & 0.6029 \\
\hline & $\left(\mathrm{D}_{2}\right)$ & $\hat{\mathrm{Y}}=9.73+0.058 * * \mathrm{X}$ & 0.0966 \\
\hline \multirow[t]{2}{*}{ RDM } & $\left(\mathrm{D}_{1}\right)$ & $\hat{Y}=31.94-0.604 * X+0.0035 * X^{2}$ & 0.5760 \\
\hline & $\left(\mathrm{D}_{2}\right)$ & $\hat{Y}=-19.89+0.59 * X-0.0032 * X^{2}$ & 0.4888 \\
\hline TDM & $\left(\mathrm{D}_{1}\right)$ & $\hat{\mathrm{Y}}=156.80-2.79 * * \mathrm{X}+0.015^{* * *} \mathrm{X}^{2}$ & 0.3023 \\
\hline $\mathrm{ABF}$ & $\left(\mathrm{D}_{1}\right)$ & $\hat{Y}=-248.60+5.55 * * * X-0.027 * * * X^{2}$ & 0.5206 \\
\hline \multirow[t]{2}{*}{$\mathrm{ABC}$} & $\left(\mathrm{D}_{1}\right)$ & $\hat{\mathrm{Y}}=347.39-5.87 * * * \mathrm{X}+0.028 * * * \mathrm{X}^{2}$ & 0.8962 \\
\hline & $\left(\mathrm{D}_{2}\right)$ & $\hat{Y}=121.58-1.73 * X+0.00927 * X^{2}$ & 0.6224 \\
\hline \multirow[t]{2}{*}{$\mathrm{ABR}$} & $\left(\mathrm{D}_{1}\right)$ & $\hat{\mathrm{Y}}=10.54+0.122 * * \mathrm{X}$ & 0.1864 \\
\hline & $\left(\mathrm{D}_{2}\right)$ & $\hat{Y}=-40.37+1.34^{\circ} \mathrm{X}-0.00723^{*} \mathrm{X}^{2}$ & 0.8319 \\
\hline \multirow[t]{2}{*}{$\mathrm{R} / \mathrm{S}$} & $\left(\mathrm{D}_{1}\right)$ & $\hat{\mathrm{Y}}=0.092+0.00207 * * \mathrm{X}$ & 0.1904 \\
\hline & $\left(\mathrm{D}_{2}\right)$ & $\hat{Y}=-0.602+0.019^{N S} X-0.000104^{\circ} X^{2}$ & 0.8151 \\
\hline
\end{tabular}


TABLE 5. Irrigation blades and dry matter of leaves (DML), stem (DMS), root (DMR), total (DMT), biomass allocation to leaves (BAL), stems (BAS), roots (BAR) and root/shoot ratio $(\mathrm{R} / \mathrm{S})$ estimates in the potassium doses $\mathrm{D}_{1}\left(80 \mathrm{~kg} \mathrm{~K}_{2} \mathrm{O} \mathrm{ha}^{-1}\right)$ and $\mathrm{D}_{2}$ $\left(120 \mathrm{~kg} \mathrm{~K}_{2} \mathrm{O} \mathrm{ha}{ }^{-1}\right)$.

\begin{tabular}{|c|c|c|c|c|c|c|c|c|c|}
\hline \multirow{2}{*}{$\begin{array}{l}\text { Irrigation } \\
\text { Blades }\end{array}$} & \multirow{2}{*}{ Doses } & MSF & MSC & MSR & MST & $\mathrm{ABF}$ & $\mathrm{ABC}$ & $\mathrm{ABR}$ & $\mathrm{R} / \mathrm{S}$ \\
\hline & & & \multicolumn{2}{|c|}{$\left(\right.$ g plant $\left.^{-1}\right)$} & \multicolumn{5}{|c|}{$(\%)$} \\
\hline \multirow[t]{2}{*}{$80 \% \mathrm{ETc}$} & $\mathrm{D}_{1}$ & 7.81 & 14.77 & 6.02 & 29.60 & 22.60 & 56.99 & 20.30 & 0.26 \\
\hline & $\mathrm{D}_{2}$ & - & 14.37 & 6.83 & - & - & 42.51 & 20.56 & 0.25 \\
\hline \multirow[t]{2}{*}{$120 \%$ ETc } & $\mathrm{D}_{1}$ & 11.61 & 13.57 & 9.86 & 38.00 & 28.60 & 46.19 & 25.18 & 0.34 \\
\hline & $\mathrm{D}_{2}$ & - & 16.69 & 4.83 & - & - & 47.47 & 16.32 & 0.18 \\
\hline \multirow[t]{2}{*}{ Optimal $^{1}$} & $\mathrm{D}_{1}$ & 11.61 & 13.57 & - & 38.00 & $\begin{array}{c}36.61 \\
(102.78)\end{array}$ & 56.99 & - & - \\
\hline & $\mathrm{D}_{2}$ & - & 16.69 & $\begin{array}{c}7.31 \\
(92.19)^{2}\end{array}$ & - & - & 47.47 & $\begin{array}{c}21.72 \\
(92.67)\end{array}$ & $\begin{array}{c}0.27 \\
(91.35)\end{array}$ \\
\hline
\end{tabular}

In Table 6 there are the increases or decreases relative to the comparison of the estimated data on irrigation blades of 80 and $120 \%$ ETc with the blade allowing the maximum value of the variable (optimal blade).

TABLE 6. Increases or decreases, in perceptual terms, of data of vegetative organs dry matter, biomass allocation and root/shoot ratio at each level of potassium dose.

\begin{tabular}{llc}
\hline \multicolumn{2}{c}{ Variables } & Increases / Decreases (\%) \\
\hline LDM & $\left(\mathrm{D}_{1}\right)$ & 48.66 \\
SDM & $\left(\mathrm{D}_{1}\right)$ & -8.12 \\
& $\left(\mathrm{D}_{2}\right)$ & 16.14 \\
RDM & $\left(\mathrm{D}_{1}\right)$ & 63.79 \\
& $\left(\mathrm{D}_{2}\right)$ & 6.96 e 51.25 \\
$\mathrm{TDM}$ & $\left(\mathrm{D}_{1}\right)$ & 28.38 \\
$\mathrm{ABF}$ & $\left(\mathrm{D}_{1}\right)$ & 61.98 e 28.00 \\
ABC & $\left(\mathrm{D}_{1}\right)$ & -18.95 \\
& $\left(\mathrm{D}_{2}\right)$ & 11.67 \\
ABR & $\left(\mathrm{D}_{1}\right)$ & 24.04 \\
& $\left(\mathrm{D}_{2}\right)$ & 5.65 e 33.10 \\
R/S & $\left(\mathrm{D}_{1}\right)$ & 32.14 \\
& $\left(\mathrm{D}_{2}\right)$ & 5.30 e 47.33 \\
\hline
\end{tabular}

Regarding the type of adjustment for the dry leaves and stem, these results were different from those found by SILVA et al. (2010b), who found exponential adjustments, however, also found adjustments quadratic total dry mass, when the growth rate of sweet pepper cv. Atlantis under different spatial arrangements. The maximum estimates for the LDM, SDM and TDM (including fruits) were $71.67,81.16$ and $232.67 \mathrm{~g} \mathrm{plant}^{-1}$, respectively, to 126 days after transplantation, which were higher than the estimates found for these variables in this experiment.

CHARLO et al. (2011), when assessing the growth curve of the hybrid pepper Eppo, grown in pots containing coconut fiber fertigated in an oven, found that there was continuous accumulation of dry vegetable mass along the entire cultivation cycle, where a maximum of $451.50 \mathrm{~g} \mathrm{plant}^{-1}$ was achieved within 189 days after transplantation and found that the leaves and roots accounted for 15.40 and $2.6 \%$ of dry matter accumulation in plants, respectively, during this same period, which were higher and lower than that found in this study, respectively, whereas allocation of the dry mass 
of the stem was $18.90 \%$ of the dry plant 21 days after transplantation, in this case being less than the observations made in this experiment.

In Table 7 there was a significant effect on significance levels $0.1 \%$ probability of interaction of I x D and the factors I and D alone for the efficiency of the water use. In the same table there was a significant effect on significance levels of $5 \%$ probability of interaction I x D for the moisture content in sweet peppers.

TABLE 7. Summary of ANOVA for water use efficiency and water content in fruits.

\begin{tabular}{lclc}
\hline \multirow{2}{*}{ Source of variation } & \multirow{2}{*}{ GL } & \multicolumn{2}{c}{ Average squares } \\
\cline { 3 - 4 } & & WUE & $\mathrm{M}$ \\
\hline $\mathrm{I}(\% \mathrm{ETc})$ & 4 & $5.24^{* * *}$ & $0.65^{\mathrm{NS}}$ \\
$\mathrm{D}\left(\mathrm{kg} \mathrm{ha}^{-1}\right)$ & 1 & $0.81^{* * *}$ & $0.03^{\mathrm{NS}}$ \\
$\mathrm{I} x \mathrm{D}$ & 4 & $0.96^{* * *}$ & $1.13^{*}$ \\
Residues & 30 & 0.054 & 0.30 \\
\hline C.V.\% & & 6.63 & 0.57 \\
\hline
\end{tabular}

*,*** Significant at 5 and $0.1 \%$ probability by the $\mathrm{F}$ test, respectively.

For the variable efficiency of water use, the respective regression models, as shown in Figure 1 , indicated a quadratic relationship for both doses of potassium.

A.

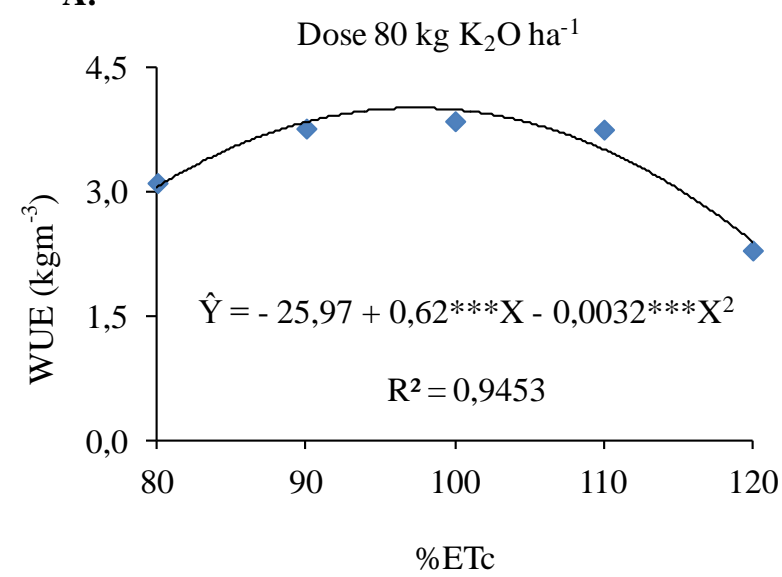

B.

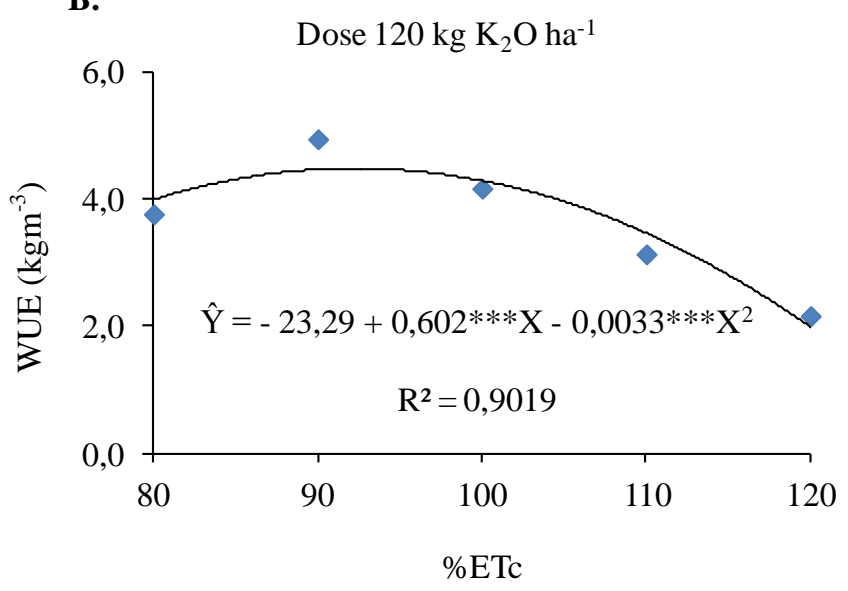

FIGURE 1. Water use efficiency (WUE) in fresh matter as a function of irrigation blades estimated in levels of potassium dose $\mathrm{D}_{1}\left(80 \mathrm{~kg} \mathrm{ha}^{-1} \mathrm{~K}_{2} \mathrm{O}\right)$ (A) and potassium dose $\mathrm{D}_{2}$ $\left(120 \mathrm{~kg} \mathrm{ha}^{-1} \mathrm{~K}_{2} \mathrm{O}\right)(\mathrm{B})$.

For the first derivative of the regression equations (Figs. 1A and 1B) estimated the optimal irrigation blade at both doses of potassium. Table 8 presents the estimates of irrigation blades and the data efficiency of water use at each dose level of potassium. It is noteworthy that the interpretation of data for optimal efficiency of water use in this experiment followed the set of quadratic functions, which were found by the first derivative of this function. However, linear adjustments can be observed in which the water use efficiency tends to decrease with increase of applied water. 
TABLE 8. Irrigation blades and water use efficiency (WUE) estimates in the potassium doses $\mathrm{D}_{1}$ $\left(80 \mathrm{~kg} \mathrm{~K}_{2} \mathrm{O} \mathrm{ha}^{-1}\right)$ and $\mathrm{D}_{2}\left(120 \mathrm{~kg} \mathrm{~K}_{2} \mathrm{O} \mathrm{ha}{ }^{-1}\right)$.

\begin{tabular}{lrc}
\hline \multirow{2}{*}{ Estimates } & \multicolumn{2}{c}{ Doses of Potassium } \\
\cline { 2 - 3 } & $\mathrm{D}_{1}$ & $\mathrm{D}_{2}$ \\
\hline Optimal blade $(\% \mathrm{ETc})$ & 97.41 & 92.30 \\
WUE maximum $\left(\mathrm{kg} \mathrm{m}^{-3}\right)$ & 4.01 & 4.48 \\
WUE $(80 \% \mathrm{ETc})\left(\mathrm{kg} \mathrm{m}^{-3}\right)$ & 3.05 & 3.98 \\
WUE $(120 \% \mathrm{ETc})\left(\mathrm{kg} \mathrm{m}^{-3}\right)$ & 2.39 & 1.98 \\
\hline
\end{tabular}

The extrapolated maximum yield per unit area as a function of potassium D1 and D2 were equal to 21.78 and $23.19 \mathrm{t} \mathrm{ha}^{-1}$, whose estimated optimal irrigation blades were 102.08 and $97.68 \%$ of ETc, respectively. For the WUE, there were increases of 31.40 and $67.38 \%$ when comparing the values obtained in irrigation blades $I_{1}$ and $I_{5}$ with the estimated maximum dose $D_{1}$. Regarding the dose $\mathrm{D}_{2}$, these increases were 12.37 and $126.51 \%$ when comparing the values observed in the irrigation blades $I_{1}$ and $I_{5}$ with the value of maximum efficiency.

This reduction observed in the result obtained in irrigation $I_{5}$ may have occurred because of stresses caused by irrigation and potassium rate excessive, increasing the electrical conductivity of the medium, leaching nutrients and causing a decrease in the yield of plants.

These observations were inferior than the observations of SOUZA et al. (2011), when evaluating the efficiency of water use in sweet pepper cv. Magali R, managed the field in no-tillage and conventional found mean values of WUE as function of the applied irrigation blades (estimated based on Class A pan evaporation) equal to 6.5 and $8.0 \mathrm{~kg} \mathrm{~m}^{-3}$ in conventional tillage systems and direct, respectively. ISMAIL (2010), also in pepper, found higher average of WUE close to $2.0 \mathrm{~kg}$ $\mathrm{m}^{-3} \mathrm{ha}^{-1}$ in the treatment with $70 \%$ of field capacity, in a study to evaluate the efficiency of water use for irrigation under water deficit.

The results obtained were similar to those obtained by AZEVEDO et al. (2005), who found a higher absolute value of efficiency of water use of $1.85 \mathrm{~kg} \mathrm{~m}^{-3}$, with the irrigation of $60 \%$ of the evaporation of Class A pan. These authors found as an average value between the treatments of $1.74 \mathrm{~kg} \mathrm{~m}^{-3}$ and variations of $0.24 \mathrm{~kg} \mathrm{~m}^{-3}$, between the irrigation blades of 60 and $80 \%$ of the evaporation of Class A pan, respectively, the lowest and highest observed value, when evaluating the effects of different drip irrigation blades based on percentage of the evaporation of class "A"pan, in the yield of pepper (C. frutescens L.) cv. Tabasco McIlhenny, at edaphoclimatic conditions of Pentecoste-CE.

In relation to the moisture in the fruit, the regression models indicated linear and quadratic relationship setting the dose of potassium $\mathrm{D}_{1}$ and $\mathrm{D}_{2}$, respectively, as shown in Figure 2.
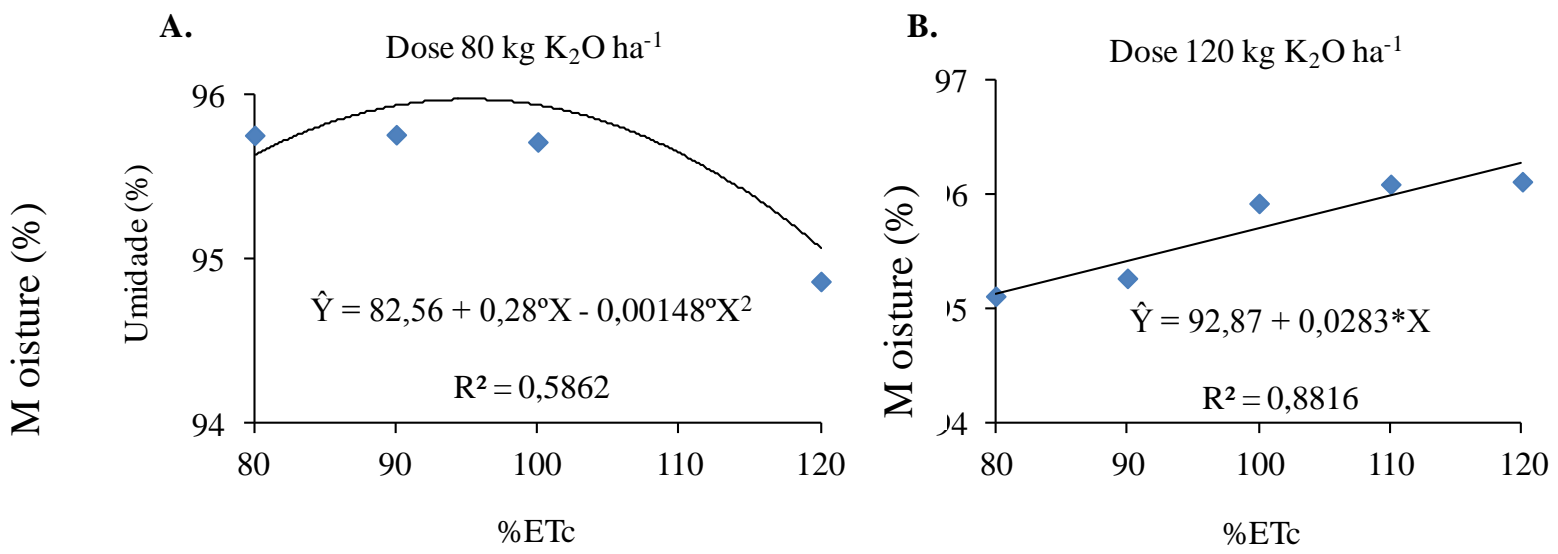

FIGURE 2. Moisture (M) as a function of irrigation blades estimated in levels of potassium dose $D_{1}$ $\left(80 \mathrm{~kg} \mathrm{~K}_{2} \mathrm{O} \mathrm{ha}^{-1}\right)(\mathrm{A})$ and potassium dose $\mathrm{D}_{2}\left(120 \mathrm{~kg} \mathrm{~K}_{2} \mathrm{O} \mathrm{ha}^{-1}\right)(\mathrm{B})$. 
For the first derivative of the regression equation, setting the dose of potassium $\mathrm{D}_{1}$ (Figure 2A), it was estimated the optimal irrigation blade. From Table 9 it is possible to observe the estimates of irrigation blades and its moisture data in pepper fruits in each dose level of potassium.

TABLE 9. Irrigation blades and moisture (M) estimates in potassium doses $\mathrm{D}_{1}\left(80 \mathrm{~kg} \mathrm{~K}_{2} \mathrm{O} \mathrm{ha}^{-1}\right)$ and $\mathrm{D}_{2}\left(120 \mathrm{~kg} \mathrm{~K}_{2} \mathrm{O} \mathrm{ha}^{-1}\right)$.

\begin{tabular}{lcc}
\hline \multirow{2}{*}{ Estimates } & \multicolumn{2}{c}{ Doses of Potassium } \\
\cline { 2 - 3 } & $\mathrm{D}_{1}$ & $\mathrm{D}_{2}$ \\
\hline Optimal blade (\%ETc) & 94.59 & 120 \\
Maximum M (\%) & 95.80 & 96.27 \\
M (80\%ETc) (\%) & 95.49 & 95.13 \\
M (120\%ETc) (\%) & 94.85 & 96.27 \\
\hline
\end{tabular}

There were increases of 0.33 and $1.01 \%$ when comparing the values obtained in irrigation blades $I_{1}$ and $I_{5}$ with the estimated maximum dose $D_{1}$. There was an increase of $1.19 \%$ when comparing the values observed in irrigation blades $L_{1}$ and $L_{5}$ with the maximum amount of moisture in the dose $\mathrm{D}_{2}$.

The moisture contents were higher than those found by RINALDI et al. (2008), who found a variation from 92.59 to $93.88 \%$ in varieties of peppers tested in the field and hydroponically (Impact, Magali and Palomar), these results were also higher than the moisture content obtained by PILON et al. (2006), who obtained a mean value of $94.16 \%$ moisture on pepper cultivar Magali minimally processed.

\section{CONCLUSIONS}

The results show that under the experimental conditions of this study, the dry biomass production of sweet pepper was influenced by fertigation regimes by changing some patterns of distribution between vegetative organs.

When the lowest dose was set, estimates of the efficiency of water use and moisture in the fruits (4.01 $\mathrm{kg} \mathrm{m}^{-3}$ and $\left.95.80 \%\right)$ occurred with the use of irrigation blade for maximum efficiency of $97 \%$ and $95 \%$ of crop evapotranspiration, respectively.

When highest dose was set, the estimates of the efficiency of water use and moisture in the fruits $\left(4.48 \mathrm{~kg} \mathrm{~m}^{-3}\right.$ and $96.27 \%$ ) occurred with the use of irrigation blade for maximum efficiency of $92 \%$ and $120 \%$ of crop evapotranspiration, respectively.

\section{ACKNOLEDGMENTS}

The authors thank the Pos-Graduate Program in Agricultural Engineering (PPGEA) UFRPE for the support and encouragement of the research, the Coordination of Improvement of Higher Education Personnel (CAPES), the National Council for Scientific and Technological Development (Cap) and the National Institute of Science and Technology in Salinity / Cap for providing grants and funding.

\section{REFERENCES}

ALBUQUERQUE FILHO, J.A.C.; LIMA, V.L.A.; MENEZES, D.; AZEVEDO, C.A.V.; DANTAS NETO, J.; SILVA JÚNIOR, J.G. Características vegetativas do coentro submetido a doses do polímero hidroabsorvente e lâminas de irrigação. Revista Brasileira de Engenharia Agrícola e Ambiental, Campina Grande, v.13, n.6, p.671-679, 2009. 
ALVAREZ, V.H.; ALVAREZ, G.A.M. Apresentação de equações de regressão e suas interpretações. Boletim Informativo da Sociedade Brasileira de Ciência do Solo, Viçosa-MG, v.28, n.3, p.28-32, 2003.

AZEVEDO, B.M.; CHAVES, S. W.P.; MEDEIROS, J.F.; AQUINO, B.F.; BEZERRA, F.M.L.; VIANA, T.V.A. Rendimento da pimenteira em função de lâminas de irrigação. Revista Ciência Agronômica, Fortaleza, v.36, n.3, p.268-273, 2005.

BERNARDO, S.; SOARES, A. A.; MANTOVANI, E.C. Manual de irrigação. 8.ed. Viçosa: UVF, 2008. $625 \mathrm{p}$.

CHARLO, H.C.O.; OLIVEIRA, S.F.; CASTOLDI, R.; VARGAS, P.F.; BRAZ, L.T.; BARBOSA, J.C. Growth analysis of sweet pepper cultivated in coconut fiber in a greenhouse. Horticultura Brasileira, Brasília, v.29, n.3, p.316-323, 2011.

FERREIRA, D.F. SISVAR: um programa para análises e ensino de estatística. Revista Symposium, Lavras, v.6, n.2, p.36-41, 2008.

FILGUEIRA, F.A.R. Novo manual de olericultura: agrotecnologia moderna na produção e comercialização de hortaliças. 3.ed. Viçosa: UFV, 2008. 421 p.

ISMAIL, S.M. Influence of deficit irrigation on water use efficiency and bird pepper production (Capsicum annuum L.). Meteorology, Environment and Arid Land Agriculture Sciences Journal, Jkau, v.21, n.2, p.29-43, 2010.

OLIVEIRA, M.V.A.M. ; VILLAS BÔAS, R.L. Uniformidade de distribuição do potássio e do nitrogênio em sistema de irrigação por gotejamento. Engenharia Agrícola, Jaboticabal, v.28, n.1, p.95-103, 2008.

PILON, L.; OETTERER, M.; GALLO, C.R.; SPOTO, M.H.F. Shelf life of minimally processed carrot and green pepper. Ciência e Tecnologia de Alimentos, Campinas, v.26, n.1, p.150-158, 2006.

PIZARRO, F. Riegos localizados de alta frecuencia (RLAF): goteo, microaspersión, exudácion. 3.ed. Madrid: Mundi-Prensa, 1996. 511 p.

RINALDI, M.M.; SANDRI, D.; RIBEIRO, M.O.; AMARAL, A.G. Características físico-químicas e nutricionais de pimentão produzido em campo e hidroponia. Ciência e Tecnologia de Alimentos, Campinas, v.28, n. 3, p.558-563, 2008.

SANDRI, D.; MATSURA, E.E.; TESTEZLAF, R. Desenvolvimento da alface Elisa em diferentes sistemas de irrigação com água residuária. Revista Brasileira de Engenharia Agrícola e Ambiental, Campina Grande, v.11, n.1, p.17-29, 2007.

SILVA, A.S.; ALMEIDA, F.A.C.; ALVES, N.M.C.; MELO, K.S.; GOMES, J.P. Característica higroscópica e termodinâmica do coentro desidratado. Revista Ciência Agronômica, Fortaleza, v.41, n.2, p. 237-244, 2010a.

SILVA, M.A.V.; NOGUEIRA, R.J.M.C.; OLIVEIRA, A.F.M.; SANTOS, V.F. Resposta estomática e produção de matéria seca em plantas jovens de aroeira submetidas a diferentes regimes hídricos. Revista Árvore, Viçosa, v.32, n.2, p.335-344, 2008.

SILVA, P.I.B.; NEGREIROS, M.Z.; MOURA, K.K.C.F.; FREITAS, F.C.L.; NUNES, G.H.S.; SILVA, P.S.L.; GRANGEIRO, L.C. Crescimento de pimentão em diferentes arranjos espaciais. Pesquisa Agropecuária Brasileira, Brasília, v.45, n.2, p.132-139, $2010 \mathrm{~b}$.

SOUZA, A.P.; PEREIRA, J.B.A.; SILVA, L.D.B.; GUERRA, J.G.M.; CARVALHO, D.F.

Evapotranspiração, coeficientes de cultivo e eficiência do uso da água da cultura do pimentão em diferentes sistemas de cultivo. Acta Scientiarum Agronomy, Maringá, v.33, n.1, p.15-22, 2011. 
SOUSA, A.E.C.; BEZERRA, F.M.L.; SOUSA, C.H.C.; SANTOS, F.S.S. Produtividade do meloeiro sob lâmina de irrigação e adubação potássica. Engenharia Agrícola, Jaboticabal, v.30, n.2, p.271-278, 2010.

TRANI, P.E.; CARRIJO, O.A. Fertirrigação em hortaliças. Campinas: Instituto Agronômico, 2004. 53 p. (Boletim Técnico, 196). 